\title{
Upaya Menurunkan Perilaku Agresif melalui Pemberian Layanan Konseling Kelompok pada Siswa
}

\section{Efforts to Reduce Aggressive Behavior through Providing Group Counseling Services to Students}

\author{
Ondawati \\ SMP Negeri 2 Jatinangor, Sumedang, Jawa Barat, Indonesia \\ ondawati2017@gmail.com
}

Naskah diterima tanggal 22/02/2019, direvisi akhir tanggal 22/04/2019, disetujui tanggal 30/04/2019

\begin{abstract}
Abstrak
Dengan banyaknya permasalahan yang terjadi di kelas VIII/A SMP Negeri 2 Jatinangor Kabupaten Sumedang terutama masalah pertengkaran diantara anggota kelas tersebut maupun dengan kelas lain yang disebabkan karena rasa marah, sakit hati ataupun kesalahpahaman. Hal ini menyebabkan sering terganggunya kegiatan pembelajaran di kelas tersebut, sehingga penulis berusaha mengadakan penelitian tentang upaya penurunan perilaku agresif bertengkar di sekolah melalui pemberian layanan konseling kelompok. Perilaku agresif adalah suatu perilaku yang bertujuan nuntuk melukai orang lain baik baik secara verbal maupun non verbal, secara fisik maupun psikis, langsung maupun tidak langsung. Untuk mengurangi frekuensi peserta didik VIII/A yang berperilaku agresif bertengkar di sekolah peneliti memberikan layanan konseling kelompok dengan kelompok besar dan kelompok kecil secara berkelanjutan. Mereka diberi kesempatan untuk menyampaikan permasalahan pengalaman, uneg-uneg yang mereka alami ataupun mereka memberikan masukan, saran pendapat ataupun sanggahan kepada kelompok atau teman yang lain. Dengan suasana kelompok yang terbuka dan penuh kekeluargaan mereka merasa senasib dan memiliki tanggung jawab bersama untuk menyelesaikan permasalahan dengan memanfaatkan dinamika kelompok. Hasil penelitian menunjukkan bahwa melalui layanan konseling kelompok dapat menurunkan perilaku agresif bertengkar di sekolah sebesar $65 \%$ dengan jumlah penurunan dari 11 peserta didik berperilaku agresif dalam satu minggu berkurang menjadi 4 peserta didik.Dengan penurunan jumlah peserta didik sebanyak 7 peserta didik merupakan penurunan yang cukup signifikanHal ini menunjukkan bahwa melalui pemberian layanan konseling kelompok dapat menurunkan perilaku agresif bertengkar di sekolah pada peserta didik kelas VIII/A. SMP Negeri 2 jatinangor Kabupaten Sumedang.
\end{abstract}

Kata kunci: konseling kelompok, perilaku agresif

\begin{abstract}
With the many problems that occur in class VIII/A Jatinangor Middle School 2, Sumedang District, especially the problem of fighting between members of the class and other classes due to anger, hurt or misunderstanding. This causes frequent disruption of learning activities in the class, so the authors try to conduct research on efforts to reduce aggressive fighting behavior in schools through the provision of group counseling services. Aggressive behavior is a behavior that aims to harm other people both verbally and non-verbally, physically and psychologically, directly or indirectly. To reduce the frequency of students VIII/A who behave aggressively fighting in schools researchers provide counseling services for groups with large groups and small groups on an ongoing basis. They are given the opportunity to convey issues of experience, as they are experienced or they provide input, suggestions or opinions to other groups or friends. With a group atmosphere that is open and full of kinship they feel the same and have a shared responsibility to solve problems by utilizing group dynamics. The results of the study show that through counseling services the group can reduce aggressive behavior in
\end{abstract}


school by $65 \%$ with a decrease of 11 students behaving aggressively in one week reduced to 4 students. With the decrease in the number of students as many as 7 students was a significant decrease. This shows that through the provision of counseling services groups can reduce aggressive fighting behavior in school for class VIII/A students. Jatinangor State Middle School 2 Sumedang District.

Keywords: aggressive behavior, group counseling

\section{PENDAHULUAN}

Peran bimbingan dan konseling di sekolah dalam Implementasi kurikulum 2013 adalah membimbing perkembangan pribadi, sosial, belajar, dan karir siswa berikutnya juga memfasilitasi advokasi, aksesbilitas serta memahami potensi dan pengembangan kesiapan belajar siswa, merancang ragam program pembelajaran, dan melayani kekhususan kebutuhan siswa. selain itu juga menguatkan pembelajaran yang mendidik serta mendorong terjadinya internalisasi nilai sebagai proses individuasi siswa. Memahami kesiapan belajar siswa dan penerapan prinsip bimbingan dan konseling dalam pembelajaran, melakukan asesmen potensi siswa, melakukan diagnostik kesulitan perkembangan dan belajar siswa, menyelenggarakan fungsi Outreach, dan membangun hubungan kerja sama dengan institusi terkait lainnya untuk membantu perkembangan siswa secara optimal.

Sekolah merupakan salah satu konteks sosial yang penting bagi perkembangan siswa, meskipun demikian perkembangan siswa juga sangat dipengaruhi oleh konteks sosial yang lainnya yaitu relasi dengan teman. Perkembangan siswa yang dimaksud dalam sekolah tentu saja lebih menuju pada perkembangan sikapnya dalam mengikuti aktivitas belajar di sekolah dan hasil belajar yaitu prestasi belajar yang diperoleh.Siswa dalam tingkat pendidikan Sekolah Menngah Pertama adalah individu yang sedang dalam masa perkembangan, dimana mereka senang dengan penjelajahan, mencari sesuatu yang baru sebagai bahan pertimbangan dalam mencari jati dirinya. Dalam masa pencarian jati diri tidak jarang mereka menemukan permasalahan atau persoalan dimana permasalahan tersebut dapat mereka selesaikan sendiri yang membuat dirinya semakin kaya pengalaman hidup namun kadang permasalahan itu tidak dapat mereka selesaikan sendiri yang membuat dirinya terbebani dan menghambat tugas tugas perkembangan dirinya. siswa yang mengalami hambatan dalam perkembangan dirinya biasanya mempengaruhi dalam hubungan sosialnya.

Berdasarkan pengamatan penulis sebagai salah seorang guru Bimbingan dan Konseling di SMP Negeri 2 Jatinangor Kabupaten Sumedang menemukan permasalahan yang sering terjadi antar siswa, khususnya siswa di kelas VIII-A, dalam hubungan sosialnya sering mengalami permasalahan yang di manifestasikan atau diwujudkan dalam perilaku agresif. Mereka sering bertengkar dengan teman, mulai dari mengejek, mengolok olok, mengancam, beradu fisik, memukul, menendang dan sebagainya. Perilaku tersebut merupakan bagian dari pelampiasan emosi siswa dimana mereka kurang memiliki daya pengendalian diri yang kuat sehingga untuk kepuasan hatinya mereka menyerang baik fisik maupun psikis orang lain ataupun dirinya sendiri

Permasalahan yang ditemukan di kelas salah satunya tidak lepas berasal dari faktor lingkungan. mayoritas siswa di sekolah tersebut adalah dari anak-anak di 
sekitar lingkungan sekolah tersebut termasuk daerah yang lokasi rumahnya sangat berdempetan antara yang satu dengan yang lain atau dengan kata lain lokasinya sempit. Hal itu memungkinkan dapat berpengaruh pula terhadap terjadinya perilaku agresif karena kemungkinan mereka merasa kurang nyaman dalam pergaulan di lingkungannya sehingga perasaannya itu terbawa ke sekolah. Secara khusus perilaku-perilaku tersebut menunjukan gangguan-ganguan yang disebabkan oleh proses belajar yang tidak semestinya, seperti gangguan mempelajari jenis-jenis kemampuan yang diperlukan seperti bersosialisasi, atau terlanjur mempelajari bentuk-bentuk perilaku yang mal-adaptif misalnya, siswa yang tumbuh menjadi remaja agresif karena meniru perilaku orangtua dan tekanan keadaan di dalam keluarga atau lingkungan sekitar yang tidak harmonis,

Sebagai referensi dan tindakan awal dari penelitian ini, peneliti mencari bahan masukan dari kegiatan penelitian terdahulu yang memiliki kesamaan dari asfek yang menjadi bahan penelitian. Penelitian terdahulu adalah penelitian yang sudah dilakukan sebelumnya oleh penelitian lain. Tujuannya adalah sebagai bahan masukan bagi peneliti dan untuk membandingkan antara penelitian yang satu dengan yang lain.

Penelitian ini berfokus pada mengatasi perilaku agresif melalui Konseling kelompok. Salah satunya adalah penelitian tindakan kelas yang dilakukan Aidha (2013) mengenai penerapan Konseling kelompok dengan teknik diskusi kelompok untuk menurunkan prilaku Agresif siswa kelas VIII D di SMP Ngariboyo menunjukkan bahwa layanan konseling kelompok dengan teknik diskusi dapat menurunkan prilaku agresif siswa. Sehingga dapat disimpulkan adanya penurunan prilaku agresif siswa yangdiberi layanan Konseling kelompok dengan menggunakan teknik diskusi kelompok. Selain penelitian tersebut, terdapat penelitian lain yang meneliti mengenai tema ini, yaitu Aulya, Ilyas, \& Ifdil (2016); Damayanti (2016); Dewi, Thalib, \& Munifah (2017); Febriyanto (2016); Hartini (2018); Heriansyah (2017); Nur Aini (2018); Puspitasari (2014); Sari (2012)

Dari penelitian-penelitian di atas, dapat disimpulkan bahwa Konseling kelompok merupakan suatu hal yang dapat ditingkatkan untuk mencapai tujuan belajar yang diinginkan. Kurangnya motivasi belajar akan berpengaruh terhadap proses penanganan prilaku bulying sehingga tidak mampu untuk mencapai tujuan belajar secara optimal. Hal inilah yang banyak siswa alami, oleh karena itu peneliti tertarik untuk meneliti masalah ini.

Perilaku agresif sering dikonotasikan sebagai sesuatu yang negatif dan suatu perusakan atau penyerangan, sehingga orang yang berperilaku agresif sering dianggap seseorang yang berbadan tinggi besar dan menakutkan karena dianggap mereka akan mengadakan penyerangan fisik. Penafsiran tersebut tidak semuanya salah namun tidak juga benar secara keseluruhan, ada sesuatu yang benar tapi ada juga kekeliruannya Perilaku agresif dapat dipahami sebagai suatu perilaku yang bertujuan untuk melukai orang lain baik secara verbal maupun non verbal, secara fisik maupun psikis, langsung maupun tidak langsung. Oleh karena itu, perilaku agresif merupakan perilaku atau sikap bermusuhan, mengancam perilaku atau tindakan yang mengancam orang lain (Anantasari, 2006:80).

Perilaku agresif merupakan tindakan intimidasi yang dilakukan secara berulangulang oleh pihak yang lebih kuat terhadap pihak yang lebih lemah, dilakukan dengan sengaja dan bertujuan untuk melukai korbannya secara fisik maupun emosional 
(Coloroso, 2007). Sementara itu Astuti (2008:28), menyatakan bahwa perilaku agresif merupakan perilaku yang dilakukan secara berulang-ulang dan terus menerus, terdapat kekuatan yang tidak seimbang antara pelaku dan korbannya, serta bertujuan untuk menyakiti dan menimbulkan perasaan tertekan bagi korbannya. Perilaku agresif dapat dikategorikan sebagai bentuk gangguan emosional, biasanya timbul karena ketidakmampuan individu menyesuaikan diri dengan lingkunganya, yangdiwujudkan dalam bentuk perilaku agresif atau pemencilan dan penarikan diri. Keagresifan siswa merupakan kesalahan dalam penyesuaian diri, berbentuk kenakalan, kebrutalan, kekerasan, dan kemarahan (Puspitasari, 2014). Lingkungan peserta didik diwarnai dengan perilaku agresif sehingga agresifitas menjadi pola interaksi, terbentuk pada setiap anggotanya secara mekanistik, melalui pembiasaan.

Pada dasarnya perilaku Agresif pada siswa adalah tindakan yang bersifat kekerasan, yang dilakukan oleh siswa terhadap sesamanya (Rahmi, 2018). Dalam agresi terkandung maksud untuk membahayakan atau mencederai orang lain. Terdapat beberapa faktor yang dapat menimbulkan perilaku agresif pada diri seseorang antara lain: a) amarah merupakan emosi yang memiliki ciri-ciri aktifitas sistem saraf parasimpatik yang tinggi dan adanya perasaan tidak suka yang sangat kuat yang biasanya disebabkan adanya kesalahan, yang mungkin nyata-nyata salah atau mungkin juga tidak. b) kekecewaan, sakit fisik, penghinaan, atau ancaman sering memancing amarah dan akhirnya memancing agresi dan c) ejekan dan ancaman merupakan pancingan yang jitu terhadap amarah yang akan mengarah pada agresi.

Perilaku agresif yang terjadi di lingkungan pendidikan jika tidak segera ditangani, di samping dapat menggangu proses pembelajaran, juga akan menyebabkan siswa cenderung untuk beradaptasi pada kebiasaan buruk tersebut. Situasi demikian akan membentuk siswa untuk meniru dan berperilaku agresif pula, sehingga perilaku agresif siswa di sekolah dianggap biasa dan akan semakin meluas.

Dalam pandangan yang optimis, menurut Aulya et al. (2016) menjelaskan perilaku agesif bukan suatu perilaku yang dengan sendirinya ada di dalam diri manusia (not innately given), tetapi merupakan perilaku yang terbentuk melalui pengalaman dan pendidikan. Dengan demikian, siswa yang mempunyai perilaku agresif, melalui pengalaman dan pendidikan perilakunya dapat diubah menjadi perilaku yang lebih positif. Banyak penelitian yang menyimpulkan bahwa munculnya perilaku agresif terkait dengan rendahnya keterampilan sosial anak, di samping itu juga terkait dengan rendahnya kemampuan anak dalam mengatur/ mengelola emosinya. Dengan demikian, melalui pembelajaran keterampilan sosial dan emosional, perilaku agresif siswa di sekolah diharapkan dapat direduksi.

Sekolah, seharusnya menjadi tempat yang menyenangkan, tempat yang aman dan sehat, tempat di mana para siswa dapat mengembangkan berbagai potensi yang mereka miliki dengan sepenuhnya. Namun, masuk ke dalam lingkungan sekolah bagi seorang siswa ternyata tidak selalu menyenangkan, mungkin malah sebaliknya bisa membuat mereka stress, cemas dan takut. bayangan akan terjadinya tindak kekerasan saat memasuki lingkungan sekolah sering menghantui siswa.

Pada dasarnya perilaku agresif pada siswa adalah tindakan yang bersifat kekerasan, yang dilakukan oleh siswa terhadap sesamanya. Dalam tindakan agresifnya terkandung maksud untuk 
membahayakan atau mencederai orang lain. perilaku agresif juga dapat disebut sikap bermusuhan yang ada dalam diri siswa. Perilaku agresif diindikasikan antara lain oleh tindakan untuk menyakiti, merusak, baik secara fisik, psikis, maupun sosial. Sasaran orang yang berperilaku agresif tidak hanya ditujukan kepada musuh tetapi juga kepada benda-benda yang ada dihadapanya yang memberi peluang bagi dirinya untuk merusak. Perilaku menyerang, memukul, dan mencubit yang ditunjukan oleh siswa bisa dikategorikan sebagai perilaku Agresif. Perilaku ini muncul karena siswa merasa frustasi menghadapi lingkungan yang sulit ia kendalikan atau tidak sesuai dengan keinginannya

Menurut Abidin, (2013;12), kekerasan dalam bentuk fisik maupun verbal di kalangan siswa telah menjadi sebuah masalah serius yang ada di berbagai negara di seluruh dunia. Perilaku agresif siswa telah menimbulkan dampak negatif, baik bagi siswa itu sendiri maupun bagi orang lain. siswa yang mengalami kekerasan akan mengalami masalah di kemudian hari baik dalam hal kesehatan juga kehidupanya. jika perilaku agresif yang terjadi di lingkungan sekolah tidak segera ditangani, di samping dapat menggangu proses pembelajaran, juga akan menyebabkan siswa cenderung untuk beradaptasi pada kebiasaan buruk tersebut. Semakin sering siswa dihadapkan pada perilaku agresif, siswa akan semakin terbiasa dengan situasi buruk tersebut, kemampuan siswa untuk beradaptasi dengan perilaku agresif akan semakin tinggi, dan akan berkembang pada persepsi siswa bahwa perbuatan agresif merupakan perbuatan biasabiasa saja, apalagi jika keadaan ini diperkuat dengan perilaku sejumlah guru yang cenderung agresif pula ketika menghadapi siswanya. Situasi demikian akan membentuk siswa untuk meniru dan berperilaku agresif pula, sehingga perilaku agresif siswa di sekolah dianggap biasa dan akan semakin meluas.

Perilaku-perilaku agresif dimanifestasikan keluar supaya dapat diamati oleh orang lain. Oleh karena itu, menurut Ma'ruf Hidayat (2015:37) menilai siswa yang memilki kecenderungan perilaku agresif atau tidak, guru atau konselor dapat mengidentifikasi dan melihatnya berdasarkan ciriciri sebagai berikut: siswa seringkali berbohong, walaupun ia seharusnya berterus terang, menyontek, meskipun seharusnya tidak perlu menyontek. suka mencuri, atau mengatakan ia kecurian bila barangnya tidak ada. suka merusak barang orang lain atau barangnya sendiri, melakukan kekejaman, menyakiti orang lain, berbicara kasar, menyinggung perasaan orang lain, tidak peduli pada orang lain yang membutuhkan pertolongannya, dan suka menggangu siswa lain yang lebih kecil atau lebih lemah. Serta seringkali marah-marah, uring-uringan, memukulkan kaki tangan, menangis dan menjerit.

Untuk mengatasi prilaku agresif siswa, maka perlu dilakukan konseling kelompok. Aidha (2013:3) menjelaskan bahwa layanan bimbingan dan konseling yang memungkinkan peserta didik memperoleh kesempatan untuk pembahasan dan pengentasan permasalahan yang dialami melalui siswa dinamika kelompok. Sedangkan menurut Latipun, (2011:181) disebutkan tujuan konseling kelompok adalah sebagai berikut a) siswa belajar untuk mempercayai diri dan orang lain, b) mengembangkan pengetahuan dan perkembangan identitas yang baik. c) mengetahui kebiasaan, kebutuhan dan masalah partisipan., d) mengembangkan penerimaan diri, kepercayaan diri, harga diri untuk mencapai gambaran diri dan e) menemukan alternatif pemecahan masalah dan mengambil keputusan yang tepat dan konflik yang dialaminya.

Dalam kegiatan konseling kelompok dalam mengatasi perilaku agresif adalah dengan memberi empati, dorong siswa untuk mencurahkan perasaanya, tanggapi dengan 
bijak, jangan terlalu melindungi, tumbuhkan percaya diri dan kembangkan kemampuanya, lakukan pengamatan, dan diskusikan dengan guru, tanggapan yang bijaksana, penuh empati, dan jauh dari kesan menginterogasi, akan mendorong siswa untuk lebih terbuka.

Tujuan dari konseling kelompok bagi siswa yang memiliki perilaku agresif adalah belajar untuk mempercayai diri dan orang lain. berikutnya adalah mengembangkan pengetahuan dan perkembangan identitas yang baik, mengembangkan penerimaan diri, kepercayaan diri, harga diri untuk mencapai gambaran dirinya, dan menemukan alternatif pemecahan masalah dan mengambil keputusan yang tepat dan konflik yang dialaminya.

Teknik yang digunakan dalam konseling kelompok, mengingat dalam konseling kelompok dituntut adanya peran serta atau dukungan dari anggota kelompok agar tercapai tujuan atau memecahkan persoalan yang dihadapi bersama maka diperlukan adanya keterbukaan dan kesadaran dari tiap tiap individu untuk memberikan keterangan dan masukan secara jujur agar dapat diambil langkah langkah penyelesaian yang tepat dan bermakna. Adapun teknik yang digunakan dalam konseling kelompok dengan melalui tahapn sebagai berikut a) tahap pembentukan, b) tahap peralihan, c) tahap pelaksanaan kegiatan dan d) tahap pengakhiran.

Dalam konseling kelompok terdapat dinamika kelompok, Dinamika kelompok merupakan motor penggerak dalam kegiatan konseling kelompok karena dengan dinamika kelompok inilah para peserta konseling kelompok mendapat manfaat untuk menyelesaikan permasalahan yang dihadapinya. Dinamika kelompok yaitu rasa keterikatan yang kuat terhadap kelompok, daya tarik kegiatan kelompok bagi masing masing anggota, relevansi dari sikap, pandangan dan perilaku yang akan diubah bagi semua anggota kelompok, penghargaan dari anggota yang satu terhadap yang lain, sehingga semua sumbangan pikiran dan perasaan diakui dan diterima. Kesempatan bersama mengenai tuntutan untuk merubah diri dan ke arah mana perubahan ini harus diusahakan.

Dari uraian di atas dapat diketahui bahwa konseling kelompok dapat membantu siswa untuk saling berinteraksi dalam kelompok dan memanfaatkan dinamika kelompok serta mampu mandiri dalam mengambil keputusan. Melalui dinamika kelompok yang intensif, pembahasan topiktopik itu dapat mendorong pengembangan perasaan, pikiran, persepsi, wawasan dan sikap yang menunjang perwujudan tingkah laku yang lebih efektif, yakni peningkatan kemampuan berkomunikasi baik verbal maupun nonverbal para siswa yang merupakan salah satu syarat terwujudnya interaksi sosial (Ma'ruf Hidayat, 2015:11).

\section{METODOLOGI PENELITIAN}

Untuk mengatasi permasalahan tentang prilaku agresif seperti diuraikan diatas, maka penulis bermaksud untuk memberikan layanan konseling kelompok yaitu layanan bimbingan dan konseling yang memungkinkan peserta didik memperoleh kesempatan untuk pembahasan dan pengentasan permasalahan yang dialaminya melalui dinamika kelompok ,masalah yang dibahas itu adalah masalah pribadi yang dialami oleh masing masing anggota kelompok.

Adapun tujuan yang ingin dicapai dari kegiatan penelitian tindakan ini adalah a) mengetahui teknik layanan konseling kelompok dalam upaya menurunkan perilaku agresif siswa b) mengetahui proses pelaksanaan teknik layanan konseling kelompok dalam upaya untuk menurunkan perilaku agresif siswa dan c) mengetahui 
tanggapan siswa terhadap teknik layanan konseling kelompok untuk menurunkan perilaku agresif

Sedangkan untuk jenis penelitian yang dilaksanakan adalah penelitian tindakan bimbingan dan konseling, penelitian tindakan bimbingan dan konseling paling sedikit dilakukan dalam dua siklus. Artinya, untuk melihat perubahan ke arah peningkatan kualitas dan hasil suatu kegiatan layanan dapat diketahui lewat perubahan dari suatu tahapan (siklus) ke tahapan berikutnya (siklus berikutnya). Pemberian layanan dilakukan sampai perbaikan atau peningkatan yang diharapkan tercapai (sesuai kriteria keberhasilan).

Penelitian ini dilakukan dalam dua siklus. Artinya, untuk melihat perubahan ke arah peningkatan kualitas dan hasil suatu kegiatan layanan dapat diketahui lewat perubahan dari suatu tahapan (siklus) ke tahapan berikutnya (siklus berikutnya). Pemberian layanan dilakukan sampai perbaikan atau peningkatan yang diharapkan tercapai (sesuai kriteria keberhasilan) dan/ atau setiap siklus paling tidak ada dua kali tindakan.

Adapun tempat penelitian yaitu di SMP Negeri 2 Jatinangor Kabupaten Sumedang, Jalan Letda Lukito desa Cisempur Kecamatan Jatinangor Kabupaten Sumedang. yang menjadi subyek penelitian adalah siswa kelas VIII/A yang berjumlah 37 anak dengan jumlah laki laki 19 dan perempuan 18. Berdasar laporan kegiatan Bimbingan dan Konseling menunjukkan bahwa kelas VIII/A paling banyak terjadi permasalahan baik dengan teman satu kelas maupun dengan teman lain kelas. Penyebab permasalahan kebanyakan karena kurangnya pengendalian diri, mudah emosi.

Teknik pengumpulan data yang diperlukan dalam penelitian tindakan kelas ini peneliti menggunakan teknik Observasi,
Wawancara, Studi dokumentasi dan Angket. Sedangkan untuk langkah-langkah prosedur kerja yang dipergunakan menggunakan tahapan-tahapan penelitian tindakan kelas yang terdiri dari dua siklus, masing-masing siklus terdiri dari empat tahapan, yaitu pertama melakukan perencanaan, berikutnya implementasi/Tindakan, observasi, evaluasi dan refleksi.

1. Perencanaan

Mendiagnosis permasalahan belajar siswa, penyebab dan dirumuskan implementasi penanganannya termasuk dalam perencanaan langkah-langkah bimbingan konseling, analisa data tentang klien, diagnosis masalah diagnosis masalah prognosis atau prediksi tentang perkembangan masalah selanjutnya, pemecahan masalah.

2. Implementasi atau Tindakan.

Pada implementasi guru menyusun pelaksanaan bimbingan konseling menggunakan Konseling kelompok dalam upaya menurunkan perilaku agresif, guru mengamati penanganan permasalahan belajar siswa.

3. Pengamatan atau Observasi.

Dalam tahapan pengamatan ini penulis tidak hanya sebagai pengamat, tetapi juga terlibat langsung dalam suatu proses situasi dan kondisi pembimbingan. kemudian penulis meminta guru $\mathrm{BP} / \mathrm{BK}$ lain untuk menjadi observer, Bentuk kerja sama atau kolaborasi di antara penulis dan observer dalam mengamati situasi dan kondisi pembimbingan itulah yang menyebabkan suatu proses dapat berlangsung.

4. Refleksi.

Pada tahap refleksi ini observer dan penulis mendiskusikan hasil tindakan masalah yang terjadi. Dengan demikian refleksi dapat ditentukan setelah adanya implementasi tindakan dan monitoring observer. 


\section{HASIL DAN PEMBAHASAN}

\subsection{Hasil Penelitian}

Pada kondisi awal penulis menjumpai masalah pada kebiasaan perilaku peserta didik kelas VIII/A. yang sering membikin ulah terutama perilaku emosional dan cenderung agresif sehingga hampir setiap hari ada kejadian tentang kelas terjadi pertengkaran di sekolah. Berdasarkan hasil pretest terhadap siswa mengenai perilaku agresif sebelum mendapatkan konseling kelompok diperoleh data sebagai berikut:

Tabel 1. Perilaku Agresif Siswa Sebelum Diberikan Layanan

\begin{tabular}{cccc}
\hline Skala nilai & $\begin{array}{c}\text { Kriteria } \\
\text { agresif }\end{array}$ & $\mathbf{f}$ & $\mathbf{\%}$ \\
\hline $81 \%-100 \%$ & Sangat Tinggi & 1 & $3,6 \%$ \\
\hline $61 \%-80 \%$ & Tinggi & 3 & $8,3 \%$ \\
\hline $41 \%-60 \%$ & Sedang & 4 & $11,1 \%$ \\
\hline $21 \%-40 \%$ & Rendah & 1 & $3,6 \%$ \\
\hline$\leq 20 \%$ & Sangat rendah & - & $0 \%$ \\
\hline
\end{tabular}

Berdasarkan tabel 1 dapat diketahui bahwa tingkatan perilaku agresif setiap siswa terbagi menjadi lima kriteria, yaitu sangat tinggi, tinggi, sedang, rendah, dan sangat rendah. Perilaku agresif sangat tinggi dimiliki oleh 1 siswa, perilaku agresif dengan kategori tinggi dimiliki 3 orang siswa.

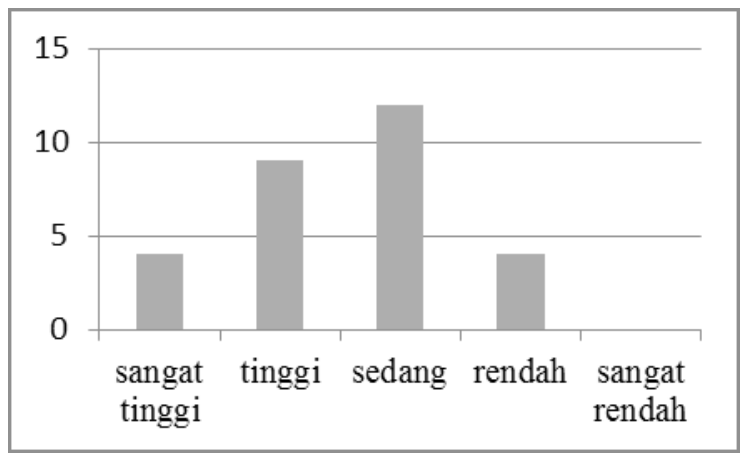

Grafik 1. Perilaku Agresif Siswa Sebelum Mendapatkan Layanan

Berikut akan dijelaskan mengenai perilaku agresif apa saja yang dimiliki siswa berdasarkan grafik 1 dapat dipahami bahwa perilaku agresif yang paling banyak dimiliki siswa yaitu: marah tanpa alasan Jurnal Penelitian Pendidikan saat di kelas, menghina temannya terkait orangtua, menghina teman terkait keadaan fisik temannya, tidak disiplin saat di sekolah, mencontek saat ulangan, menjawab saat dinasehati oleh guru, tidak melaksanakan apa yang diperintahkan guru, membuat gaduh saat di kelas, berbicara dengan teman saat guru menerangkan, menyuruh teman, memukul, menendang, dan memukul teman dengan penggaris.

Perilaku agresif menghina teman yang sering ditunjukkan siswa yaitu menghina siswa saat ada siswa yang maju ke depan, biasanya mereka menghina terkait keadaan fisik temannya. Selain itu, siswa juga menghina temannya dengan menyebutnyebutkan nama orangtua temannya dan pekerjaan orangtuanya. Contoh tindakan menghina terkait keadaan fisik yaitu seperti, dasar pendek bodoh!. Sedangkan contoh menghina terkait orangtuan yaitu seperti, dasar anak tukang ojek!, dan lain sebagainya.

Perilaku tidak disiplin yang ditunjukkan siswa, yaitu seringnya mereka terlambat masuk ke kelas selesai jam istirahat. Terutama siswa laki-laki cenderung suka berkeliaran saat jam kosong, dan berlamalama di kantin saat jam istirahat. Selain itu, ada beberapa siswa yang sering datang terlambat ke sekolah.

Perilaku kurang disiplin yang paling banyak ditunjukkan siswa yaitu mengenai seragam mereka, hampir semua siswa memakai seragam dengan tidak rapi yaitu membiarkan baju mereka keluar tanpa dimasukkan kedalam celana. Perilaku mencontek yang paling sering ditunjukkan siswa adalah pada saat ada PR, siswa sengaja berangkat pagi-pagi untuk mencontek pekerjaan rumah temannya. Selain itu, mereka juga mencontek saat diberikan tugas oleh guru kelas.

Perilaku ribut di kelas, adalah yang paling banyak dimiliki siswa berdasarkan 
hasil wawancara dengan siswa, mereka mengaku sering ribut karena bosan dengan pelajaran yang diberikan. Hampir semua siswa terutama anak-anak laki-laki memilih ribut dan berbicara sendiri saat pelajaran, bahkan ada satu diantara mereka yang juga memukul meja sambil menyanyi-nyanyi, seperti sedang menabuh kendang.

Perilakutidakmendengarkanguru, baik saat pelajaran maupun saat guru menasehati berkaitan langsung dengan perilaku ribut di kelas. Siswa laki-laki terkadang justru tertawa sendiri saat guru sedang menasehati atau sedang membimbing. Mereka berbicara dengan teman sebangkunya, bermain di kelas, dan mengerjakan hal lain. Untuk mengurangi perilaku agresif di kelas VIII-A, maka penulis membuat layanan konseling kelompok. Sebagai suatu teknik pemberian layanan harus selalu mengikuti prosedur yang sistematis dalam penyelenggaraannya.

Setelah melaksanakan bimbingan kelompok dengan menggunakan teknik konseling kelompok pada siklus 1, untuk mengetahui perilaku agresif siswa, maka peneliti melaksanakan posttest. Berdasarkan hasil posttest terhadap siswa mengenai perilaku agresif setelah mendapatkan layanan konseling kelompok, dalam kurun waktu dua minggu diperoleh data sebagai berikut.

Tabel 2. Perilaku Agresif Siswa Setelah Memperoleh Layanan

\begin{tabular}{cccc}
\hline Skala nilai & $\begin{array}{c}\text { Kriteria } \\
\text { agresif }\end{array}$ & $\mathbf{f}$ & $\mathbf{\%}$ \\
\hline $81 \%-100 \%$ & Sangat Tinggi & 0 & $0 \%$ \\
\hline $61 \%-80 \%$ & Tinggi & 2 & $5,5 \%$ \\
\hline $41 \%-60 \%$ & Sedang & 4 & $11,8 \%$ \\
\hline $21 \%-40 \%$ & Rendah & 3 & $8,3 \%$ \\
\hline$\leq 20 \%$ & Sangat rendah & 0 & $0 \%$ \\
\hline
\end{tabular}

Berdasarkan tabel 2 dapat diketahui bahwa setelah pemberian konseling kelompok terdapat perubahan pada perilaku siswa. Pada grafik 2, dari sembilan orang siswa lakilaki di kelas VIII-A, terdapat 3 siswa yang menunjukkan perilaku agresif yang rendah, dan 4 siswa menunjukkan perilaku agresif yang sedang. Namun masih terdapat 2 orang yang berperilaku agresif dengan kategori tinggi. sementara untuk kategori sangat tinggi sudah tidak nampak lagi.

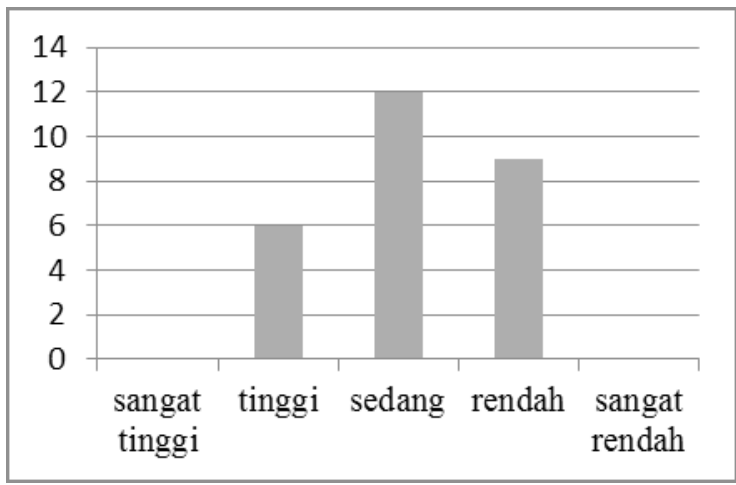

Grafik 2. Perilaku Agresif Siswa pada Siklus 1

Adapun beberapa kekurangan yang ditemukan oleh guru kolaborator pada siklus 1 dalam kegiatan konseling kelompok diantaranya adalah beberapa siswa masih belum memahami materi konseling yang dijelaskan oleh konselor, sehingga hasilnya kurang memuaskan. Setelah mendiskusikan hasil temuan berdasarkan pengamatan pada kegiatan siklus 1 yang masih terdapat kekurangan dalam kegiatan pelayanan konseling kelompok dengan, maka disepakati untuk mengadakan perencanaan perbaikan kegiatan pelaksanan kegiatan pelayanan konseling kelompok pada siklus 2. Setelah melaksanakan bimbingan kelompok dengan menggunakan konseling kelompok, maka untuk mengetahui perilaku agresif siswa, peneliti melaksanakan posttest. terhadap siswa mengenai perilaku agresif pada siklus 2 diperoleh data sebagai berikut.

Tabel 3. Perilaku Siswa Setelah Memperoleh Layanan Pada Siklus 2

\begin{tabular}{cccc}
\hline Skala nilai & $\begin{array}{c}\text { Kriteria } \\
\text { agresif }\end{array}$ & $\mathbf{f}$ & $\mathbf{\%}$ \\
\hline $81 \%-100 \%$ & Sangat Tinggi & 0 & $0 \%$ \\
\hline $61 \%-80 \%$ & Tinggi & 0 & $0 \%$ \\
\hline $41 \%-60 \%$ & Sedang & 2 & $5 \%$ \\
\hline $21 \%-40 \%$ & Rendah & 7 & $19 \%$ \\
\hline$\leq 20 \%$ & Sangat rendah & 0 & $0 \%$ \\
\hline
\end{tabular}

Jurnal Penelitian Pendidikan 
Berdasarkan tabel 3 dapat diketahui setelah pemberian konseling kelompok pada siklus 2 terdapat perubahan pada perilaku agresif siswa. Pada grafik 3, dari sembilan orang siswa laki-laki di kelas VIII-A, terdapat 7 siswa yang menunjukkan perilaku agresif rendah, dan 2 siswa menunjukkan perilaku agresif yang sedang, untuk kategori tinggi dan sangat tinggi sudah tidak nampak.

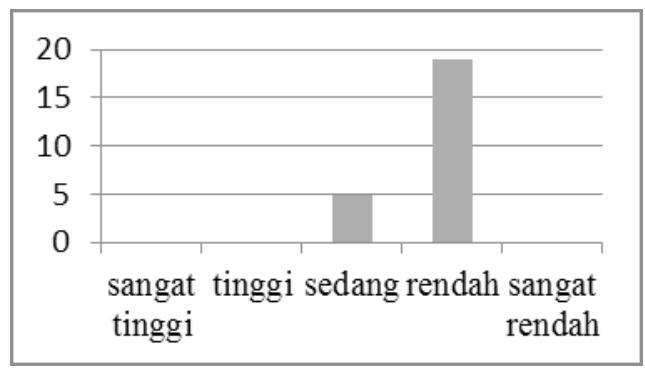

Grafik 3. Perilaku Agresif Siswa Pada Siklus 2

Dari hasil wawancara untuk mengetahui perilaku agresif siswa setelah mengikuti konseling kelompok. Berdasarkan wawancara tersebut, hampir semua siswa mengaku lebih bisa mengendalikan diri saat akan berperilaku agresif, sehingga perilaku agresif mereka dapat berkurang.

\subsection{Pembahasan}

Berdasarkan gambaran umum pelaksanaan tindakan bimbingan dan konseling tersebut maka dapat dipahami bahwa, konseling kelompok yang diberikan pada siswa untuk mengurangi perilaku agresif ini, dapat dikatakan berhasil, karena siswa mampu memahami makna dan dampak dari perilaku agresifyang selama ini mereka lakukan. Selain itu, dalam pertemuan terakhir dilakukan evaluasi serta refleksi diri siswa, yang mana hasil dari kegiatan tersebut, siswa mampu memilah-milah kebiasaan mana yang harusnya masih dipertahankan dan kebiasaan mana yang harus dikurangi, salah satunya yaitu kebiasaan berperilaku agresif.

Berdasarkan hasil observasi terhadap siswa, didapatkan hasil bahwa sebelum diberikan layanan, siswa laki-laki memiliki perilaku agresif yang tinggi. siswa menunjukkan perilaku agresif verbal yaitu marah tanpa alasan, menghina, mengancam, membuat permintaan yang tidak pantas, membuat gaduh saat di kelas, dan tidak disiplin. Selain itu, sebagian besar siswa lakilaki menunjukkan perilaku non verbal, seperti memukul, menendang, menyerang, menyerbu, dan mengambil barang milik orang lain tanpa ijin. Perubahan yang terjadi pada siswa adalah berbeda satu dengan yang lain. Beberapa siswa mengalami penurunan yang drastis terhadap perilaku agresifnya, sedangkan yang lain hanya mengalami penurunan beberapa persen saja. Selain itu, ada siswa yang mengalami penurunan perilaku agresif setelah mengikuti layanan pada pertemuan pertama dan kedua, sedangkan ada siswa yang mengalami penurunan setelah mengikuti layanan beberapa kali pertemuan. Perbedaan penurunan tingkat perilaku agresif ini, disebabkan karena beberapa faktor diantara yaitu:

1. Dengan diberikannya layanan konseling kelompok siswa terlihat gembira dan antusias untuk mengikuti semua kegiatan dengan suka rela dan penuh kesungguhan sehingga pesan atau tujuan yang akan dicapai yaitu penurunan perilaku agresif atau perilaku bertengkar di sekolah dapat dipahami dengan benar dan selanjutnya diwujudkan dalam perilaku sehari hari di sekolah.

2. Layanan konseling kelompok dapat menurunkan jumlah perilaku agresif bertengkar di sekolah karena peserta konseling kelompok benar benar merasa nyaman dan diperhatikan. Mereka tidak merasa di nasihati tetapi mereka merasakan suasana kebersamaan untuk menyelesaikan permasalahan bersama.

Dari hasil pengamatan secara umum, berdasarkan hasil pengamatan guru kolaborator, Secara umum, siswa sepenuhnya menyadari dampak dari semua perilaku Agresif yang selama ini mereka lakukan. Siswa menunjukkan perubahan sikap mereka dari awal pertemuan sampai akhir pertemuan. 
Siswa tidak lagi berbicara sendiri, tidak lagi menghina, dan tidak disiplin. Walaupun tidak semua siswa berhenti membuat gaduh, namun sekarang mayoritas siswa tidak lagi ribut saat di kelas dan tidak lagi menghina teman yang sedang maju dan mau mengerjakan perintah guru di depan kelas.

Berdasarkan respon siswa yang dijaring melalui angket yang dibagikan kepada seluruh siswa peserta konseling kelompok, sebanyak $100 \%$ menyatakan sangat setuju bahwa layanan konseling dapat mengembangkan penerimaan diri, kepercayaan diri, harga diri untuk mencapai gambaran dirinya. Menemukan alternatif pemecahan masalah dan mengambil keputusan yang tepat dan konflik yang dialaminya.

Secara umum, penilaian perilaku agresif siswa tidak hanya dilihat dari berapa persen penurunan perilaku mereka, karena perilaku agresif pada awalnya memiliki perbedaan. Jadi, untuk melihat berhasil atau tidaknya treatment yang diberikan, peneliti juga melihat hasil akhir perilaku agresif siswa setelah diberikan treatment. Berdasarkan hasil wawancara dengan wali kelas, wawancara dengan siswa, dan observasi terhadap perilaku siswa, didapatkan hasil bahwa perilaku agresif siswa setelah mengikuti konseling kelompok menjadi rendah dan sangat rendah. Artinya, perilaku agresif siswa hampir terentaskan secara keseluruhan.

\section{KESIMPULAN}

Dari hasil penelitian yang dilaksanakan maka dapat ditarik kesimpulan bahwa gambaran perilaku agresif yang ditunjukkan siswa sebelum diberikan layanan klasikal menggunakan teknik konseling kelompok adalah marah tanpa alasan saat di kelas, menghina temannya terkait orangtua, menghina teman terkait keadaan fisik temannya, tidak disiplin saat di sekolah, mencontek saat ulangan, menjawab saat dinasehati oleh guru, tidak melaksanakan apa yang diperintahkan guru, membuat gaduh saat di kelas, berbicara dengan teman saat guru menerangkan, menyuruh teman, memukul, menendang, dan memukul teman dengan penggaris. Perilaku agresif siswa sebelum mendapatkan bimbingan kelompok dapat dikategorikan cukup tinggi.

Namun perilaku agresif siswa setelah mendapatkan layanan konseling kelompok di kelas VIII-A setelah mendapatkan konseling kelompok pada siklus 1 dan siklus 2 dapat dikategorikan mengalami penurunan. Perilaku agresif yang ditunjukkan siswa persentase kemuculannya sangatlah jarang. Perilaku agresif yang masih dimiliki siswa dengan persentase kemunculan yang paling tinggi adalah membuat gaduh saat di kelas.

Berdasarkan hasil penelitian peneliti memberikan saran yaitu: Guru diharapkan lebihmemberikanperhatiannyaterhadapsiswa yang memiliki perilaku agresif. Guru harus mampu mengarahkan serta membimbing siswa yang memiliki perilaku agresif, sehingga siswa menyadari perilakunya yang keliru dan mau memperbaiki perilakunya. Selain itu, guru juga harus lebih tegas saat menghadapi siswa yang memiliki perilaku agresif, sehingga siswa mampu menghormati guru, mendengarkan guru saat menjelaskan dan memberikan bimbingan, serta tidak lagi bersikap tidak sopan pada guru.

\section{DAFTAR RUJUKAN}

Abidin, Z. M. (2019). Mengatasi Agresif di Sekolah. [Online]. Diakses dari http://www.masbied.com

Aidha, H. P. N. (2013). Penerapan Bimbingan Kelompok dengan Teknik Diskusi Kelompok untuk Meningkatkan Motivasi Belajar Siswa Kelas VIII D SMP Negeri 1 NGARIBOYO. Jurnal BK UNESA, 3(1).

Anantasari. (2006). Psikologi Sosial. Jakarta: Gramedia.

Astuti, P. R. (2008). Meredam Bullying: 3 Cara Efektif Mengatasi Kekerasan pada Anak. Jakarta: Grasindo. 
Aulya, A., Ilyas, A., \& Ifdil, I. (2016). Perbedaan Perilaku Agresif Siswa Laki-Laki dan Siswa Perempuan. Jurnal EDUCATIO: Jurnal Pendidikan Indonesia, 2(1), 91-97. https://doi.org/10.29210/12016239

Coloroso, B. (2007). Stop Bullying! Jakarta: Serambi Ilmu Pustaka.

Damayanti, S. (2016). Efektivitas Pemberian Layanan Konseling Kelompok menggunakan Pendekatan Realita untuk Mengurangi Prilaku Agresif Siswa Kelas VII SMP Negeri 2 Grogol Tahun 2015/2016. Universitas Nusantara PGRI Kediri.

Dewi, L. L., Thalib, M. M., \& Munifah. (2017). Dalam Mengurangi Perilaku Agresif Verbal Siswa Jurusan Desain Komunikasi Visual (DKV) SMK Negeri 5 PALU. Jurnal Konseling \& Psikoedukasi, 2(2), 39-50.

Febriyanto, G. (2016). Konseling Kelompok dalam Menangani Perilaku Agresif Anak di Panti Sosial Asuhan Anak Yogyakarta unit Bimomartani. Universitas Islam Negeri Sunan Kalijaga Yogyakarta.

Hartini, S. (2018). Upaya Penurunan Tingkat Perilaku Agresif Di Madrasah Dengan Teknik Konseling Kelompok (Studi Kasus Pelanggaran Disiplin Aturan Madrasah ) Pada Siswa Klas 7 F Semester Genap Tahun Pelajaran 2016/ 2017 Mtsn Prambanan Kabupaten Klaten. LITERASI (Jurnal Ilmu Pendidikan), 8(1), 20. https://doi.org/10.21927/literasi.2017.8(1).20-35

Heriansyah, M. (2017). Strategi Mengatasi Trauma Pada Korban Bullying melalui Konseling Eksistensial. In PROCEEDING SEMINAR DAN LOKAKARYA NASIONAL REVITALISASI LABORATORIUM DAN JURNAL ILMIAH DALAM IMPLEMENTASI KURIKULUM BIMBINGAN DAN KONSELING BERBASIS KKNI (pp. 122-131).

Latipun. (2011). Psikologi Konseling (Cetakan ke-9). Jakarta: Erlangga.

Ma'ruf Hidayat. (2015). Perilaku Agresi Relasi Siswa di Sekolah; Mengenali dan Menyelesaikan Melalui Mediasi Sebaya. Yogyakarta: Aswaja Pressindo.

Nur Aini, D. F. (2018). Self Esteem Pada Anak Usia Sekolah Dasar Untuk Pencegahan Kasus Bullying. Jurnal Pemikiran Dan Pengembangan SD, 6(April), 36-46.

Puspitasari, D. N. (2014). Pelatihan Keterampilan Sosial untuk Menurunkan Perilaku Agresif Anak. Jurnal Psikologi Tabularasa, 9(1).

Rahmi, T. U. (2018). Studi Komparasi Perilaku Agresi Anak Jalanan Antara Sebelum Dan Sesudah Pembinaan (Studi Kasus : Lembaga APIK Mandiri Lampung). Universitas Lampung.

Sari, Y. M. (2012). Penggunaan Layanan Konseling Kelompok Untuk Mengurangi Perilaku Agresif Pada Siswa. Jurnal Psikologi Pendidikan Dan Bimbingan, 1(1), 1-13. 